\title{
Economic Expectations for Turkey, Central Asia and Caucasus Beyond 2050
}

\author{
Dr. Ahmet Salih İkiz (Muğla University, Turkey)
}

\begin{abstract}
In this study main international strategic theories will be shortly discussed under the time and space dimension. Almost all of the Turkic republics do have common historical and cultural ties with Turkey compared to the other European countries. Even though common values have simply forgotten during the time frame under different regimes spatial history and ties had never disappeared. Thus, the citizens of those countries preserve common spatial memory so they shared same land in history. So it is expected that those people would reach the idea of economic and political integration if certain social grounds were initiated. This is basically the idea of economic integration between those republics and Turkey for better economic standards. So, in final part of the study, author will provide his humble opinions for future expectations for 2050 and beyond.
\end{abstract}

\section{Introduction}

"In politics or geopolitics, scenario analysis involves modeling the possible alternative paths of a social or political environment and possibly diplomatic and war risks. For example, in the recent Iraq War, the Pentagon certainly had to model alternative possibilities that might arise in the war situation and had to position material and troops accordingly." (Wikipedia).

The relation between economic power geographical locations of countries is the main research area of Geoeconomics science. Geo-economics reveals the impacts of countries technology, capital, and natural resources on political power in globe. Thus it can be classified as the sub section of both economics and political science. In today's world most of the international conflict rooted by international trade interests of host countries. That increases the importance of that particular science. The globalization wave accompanied by mercantilist economic policies forced European countries penetration in the rest of world. The political elite and military command draw special attention to govern and control the rest of the globe. Implementation of this strategy backed first by British Mackinder as heartland theorem and followed by American Spykman's Rim land strategy.

British geopolitical strategy born in 19th century for the security and economic purposes of Empire. In late 19th century American Admiral Alfred Mahan published his study called The Influence of Sea power upon History. Mahan geopolitics believes countries with sea borders are easy to defend. Countries surrounded by ocean reinforce their military powers for intervention to other countries. As long as they have strong sea power they easily control world strategic points easily. In following years US geo-economics policy surrounded main energy resources and trade corridors in world by its naval force.

British academic John MacKinder wrote his book Historical Pivot of the History and introduced Heartland theory. According to the theory world strategic center heartland situated in central Asia and Volga Basin. This region is like natural castle with its topographic and geographic location. His assumption based on the geographic location of land is important. So all world can be divided to 3 geographical locations:

- Heartland (Kalpagh) Eastern Europe and Siberia

- Inner Crescent Turkey, Germany, India and China

- Crescent United Kingdom, South Africa and Japan

Thus if any country or political power rules Eastern Europe dominates Hearth land. The geopolitical center of Eurasia lies on Hearthland. So the political master of Eurasia is the world leader in geoeconomics.

After WWI the German geopolitics reinforced Lebensraum strategy for German invasion till the end of WWII. This strategy based upon the idea of Darwin's survival of the fittest theory. Every country must be considered as living organism and in order to keep the country alive it has to create its own living area for enlargement. I.e. the occupation of other countries. Following the collapse of third Reich European impact on world order diminished since most of the countries such as Brittan and France faced with devastating economic ruins. German strategy ironically reincarnated in different forms when German economic power seized most of the Balkan countries in1990's under EU umbrella. First German mark and then Euro circulated as hard currency in those countries as economic hegemonic power of Germany after couple of decades of German tanks in those countries.

That was the beginning of US empowerment in foreign policy and world order. USA policy mainly leans on containment policy due to fear of USSR war capacity. Border and edge countries like Turkey had solid support from US as a bumper. Creation of US led opposition movement in USSR neighbor countries and Turkic republics was main aim to destabilize possible Moscow penetration on western world. In those times there was almost no international relation between Turkic States and Turkey because of strict Soviet control. During the cold war world has two power polar USSR and USA. Those countries were the main determinants of pivot and 
bumper countries foreign policies. The US strategy was to impose and improve soft Islamic power around USSR. Under the green zone approach Islamic groups in periphery countries re supported. The main aim was to create artificial enemy to Marxist, atheist communist world. Containment policy is theoretical reflection of Rimland theory of Spkysman. Contrary to Hearthland theory Rimland approach focuses on crescent of Eurasian regions. In order to diminish USSR power in Eurasia US must target to improve its penetration on those countries. The North Korean, Vietnam and Afghanistan wars were main power struggles and conflict zones during the cold war since they are vital countries under this policy.

Dramatic collapse of USSR due to economic inefficiencies ended cold war period. That is also limited the global political power of USSR. Fransis Fukuyama called that The End of History where the US led economic system will be the unique in world order. In same time frame Huntington announced the new paradigm as Clash of Civilizations. According to him there are five different civilizations in world Orthodox, Catholic, Islam, Indian and Japan. The borders of those civilizations are new breaking points between countries. Countries with different cultures would have problems in their countries such Former Yugoslav countries. This is what he called the clash of civilizations. The war in Bosnia was one of the examples of this geographical conflict. Russian Federation was hampered by those wars during the disintegration process of USSR.

Eurasia in geological terms can be classified in narrow definition is the borders of Central Turkic Republics. In broader sense Eurasia reaches China, Afghanistan Pakistan and Russia. Those geographical definitions also reflect the Turkish and other countries approach to region. Turkey for a period of time stick to narrow definition while Russian Federation and USA concentrated on broader sense especially after 9/11. Russian Eurasian policy considered Turkey as rival country. The theoretical background of Eurasian policy had changed as it turned to opposition to westernization in cultural and economic life.

Following Putin presidency the foreign policy of Russian Federation radically changed and shaped by Dugin's Neo Eurasian philosophy. In former USSR borders establishment of Commonwealth of Independent States improved the relations with former USSR countries. In foreign security China, Russian Federation, Kazakhstan, Kirghizstan, Tajikistan and Uzbekistan founded Shanghai Security Organization. This has similar functions of NATO for those countries. This new paradigm possibly aims to solve the integration problems multiethnic Russian society. The authoritarian, state controlled economic structure and governance will create modern society without Atlantic western democratic codes in country.

In modern geo-economics the variables of spatial location, identity and economics are the main determinants of strategic analyses. In today's global society the historical legacies of ancient societies become quite significant in identity formation. Preserved identities in former USSR countries are very essential leverage for the foundation and integration of Turkic Union in that part of the world. Hard power always must be accompanied with soft power in international relations. The historical heritage of Turkish culture in those countries will serve an eminent tool for that. All these theories became much more complex in today's cyber global society where small minor change in any part of the world would create a butterfly effect in some other country.

\section{Eurasia and Turkey}

Turkish inhabitance in Eurasia starts from BC 4th in region. There were hundreds of nomads in Central Asia. The integration of those tribes created Turkic empire in Central Asia and ruled relatively long period of time. That kept security and stability from China to Byzantium on Silk Road and created Pax Turcica (Findley 57). So that identity formation with same language, cultural habits, and religious ceremonies easily created within those tribes in spatial dimension. The Chinese threat, scarce natural resources for nutrition and internal conflicts forced them to move to west in AD 11th century. Migration of tribes was also the beginning of the establishment of new civilizations and states in Anatolia. In chronological order Seljuk, Ottoman empires and finally Turkish Republic founded in this land. During the Seljuk and Ottoman empires the Central Asia still have Turkic origin Mongols. When Ottomans were transformed to Islamic dominant global state Mongols were trying to sustain their persistence in Asia. In early 16th Century Turks in Central Asia lost their independence under Russian occupation. That dimension nevertheless created Russian dominance and oppression on language and culture. So that until early 20th Century Turks living in Central Asia, Anatolia and other parts of Ottoman empire do not need any other language for communication that maintain common identity in most of the daily life. For example Findley searched the similarities of Turkish rugs and carpets in different parts of Anatolia and Central Asia and find a lot of resemblance in history. Loss of momentum of development of Ottomans and Russian policies vanished the communication of Turks in west and east especially after the WWII.

After 1917 revolution Russian central government privileged the self determination of Turkic states in language and education in order to end the traumatic totalitarian chauvinist policies of old Char regime. Thus Muslim Turks in Central Asian Republics were quite convinced and supported USSR regime for a period of time. The general discourse was the reflexive division of Islamic conservatives and contemporary nationalists. The left wing nationalists cooperated with Bolsheviks and the domain governing mind till mid-1930s (Aydin, 38). The tone and intervention of USSR policies towards Turks changed after Stalin era. The education system 
centralized by Russian alphabet, international relations of republics with foreign world restricted and central planning changed economic distribution channels radically. This is the beginning of the isolation of Central Asia from other countries but mainly Turkey. Same time Turkey joined NATO and had limited ability towards his foreign policies towards USSR. For a long period of time the case of Central Asian Turkic Republics considered as internal affairs of USSR by Turkish Republic. The Cold war period could be classified as finite political game between two polar world powers. Each party has its own strategy and tactics in economics, military and trade areas in world system. There was few relations between two blocks. Both parties have its own strategy on Turkic Republics. USSR granted limited determination in internal policies and was ultimate decision maker in international policies. US strategy based on Rimland theory and aims to create instability in those states. The soviet economic system had been working inefficiently under central planning system and it was not sustainable for long term economic growth. Coming to 1990's Increasing defense expenditures became a real burden on state budget which started disintegration process of Soviet bloc. After the disintegration, Turkic world had its own policy formation in both interior and international affairs. So after 1991 the economic and cultural and educational corporations and bilateral policies increased between Turkey and those countries. The oversimplification of differences between Anatolian Turks and Asiatic Turks sometimes created artificial relations among partners (Aydin, 8). Turkish behavior towards the region sometimes like older brother of those states which in turn created negative impacts on Turkish presence. For decades Turkic Republics experienced the same treatment and policy by USSR and got negative experiences. In order to not engage the same parental treatment they do have limited support to the integration efforts of Turkey. Thus the both parties have lost their momentum in further cooperation in different aspects of relations. For example today the foreign trade between those countries and Turkey less than $\% 3$ in Turkish whole foreign trades. Those countries still do need Russian interference since most energy infrastructure belongs to Moscow. The poor human capital and lack of education needs Russian technological manpower and engineers. The strategic shift mainly affected by Russian dominant policy in region and energy security and corridors policy became the main concern in formation Turkish international policy to Central Asian countries.

Russian policy towards Central Asia has reshaped in 2000 and this geographical region became area of interest and power infusion for Russia. The increasing economic penetration of Russia melted the power infusion of USA to Turkic world. Turkey also lost its momentum with Turkic world due to declining volume of trade. Also Russia became main player in defining the energy transport routes of those energy rich countries. The economic power of Russia backed my some military interventions to Georgia and Ukraine by stretching the mussels. The spatial ties in history survived but overshadowed by Dugins strategy in Turkic world. The Blue Stream was total bypass of supplier countries and also Russia got advantage international chess board by starting to construct Turkish Stream.

\section{Year 2050 and Beyond}

Anatolia is the harmony of eastern and western cultures. It was also the nest of many different civilizations. That enables the cohesion in much aspect with neighbor countries. This is also improves spatial tolerance between Turkish speaking world. In following part of the study I will explore possible future expectations in world political order with special emphasis on Turkic world and Turkey.

Coming years there will be the changing power blocks in world. British and following USA dominance in world order will have new global players such as, Russia, China, Japan and Turkey. The Caucasus and Central Asia will be main interest of all those countries. The World has witnessed that the growing economies like China and India have become part of the global market and integrated to the global economy in the last 20 years with rapid globalization process. With high performance of emerging economies like China and India, developed countries' share of global GDP declined, while developing countries' share increased. These trends in the global economy negatively affected the role of US and Europe used to be a dominant before and emerging new powers increased room for maneuver (MGK, 8). Kazakhstan and Turkmenistan have strong economic path and attained high growth rates. With other Turkic Republics Turkey would increase the volume of international trade and economic cooperation in coming years. Southern Caucasus is the main location for energy and transport corridors to Eurasia. The Russian interest on Azerbaijan, Georgia and Armenia starts in 13 AD where Georgian Christian tribes demanded Russian support for Turkish and Ottoman presence in region (Aydın, 27). So this region had conflict of interest with those countries. Peace, security and welfare in this region plays important role for Turkey

China has close historical ties with eastern Turkistan. The hew Silk Road project of Shanghai Security Organization improved economic bridges between those countries and China. According to World Energy Institute resources since 2009 Chinese demand of energy resources higher than US. This indicator reveals the Chinese eagerness towards Central Asia. In order to secure its energy demand by close energy supply countries this country will cooperate with Russia. As long maintain financial stability and interior stability China will be one of the main powers in region (Erkin, 268). Even if Russia and China got some imperial balance on region their international power will decline due to interior problems. China although has very fast economic growth 
rates regional differences in economic growth and education is quite high in different geographical parts of the country. Unsustainable economic achievements will create social unrest in low income masses. Meantime country got economic and military threat from Japan and USA. So it concentrates rather on internal issues and got weak interest on Turkic world. Putin's dominant strategy in region must be backed by economic and financial power. Russia never has been competitive in industrial production in world wide. That created relatively weak economic structure which is depending on export revenues of raw materials, precious metals and energy resources. By the leverage of this policy it has moved to the penetration area towards Caucuses and Eastern Europe in former borders. But there are some backward trends in Russia. First the population is seriously declining which diminishes military power which is essential to stop any threat from western borders. During the Napoleon French attack and German invasion in WWII followed flat lines close to ST Petersburg. Loss of military power and declining economic growth due to the declining energy revenues limits the size of Moscow to any other attempts to Central Asian countries. The internal conflicts of both countries will increase the impoartence of Turkey, Japan and Poland İn those region. Turkey with its special spatial memory coming from historical ties has clear advantage in construction cultural bridges between Muslim and Turkish minorities in region. Then the expected political map for 2050 in the region will be as same as the Friedman's expectations in his book (Friedman, 267).

USA support to Turkey as counter balancing power for its policies to Central Asia and Middle East is essential part of its global strategy. In order to create a contra power to Russian strategic influence on petroleum and gas resources American support for Turkey is crucial. European policy towards Russia is quite reluctant since they are heavily depending on energy supply and transport of this country. Turkey with his nephew's Kazakhstan, Uzbekistan and Turkmenistan in Central Asia planning to construct TransHazar facility for EU and its leaving Iran and Russia out of the table. This has been confronted and bypassed by Russian Turk stream pipe line attack which is totally against it.

With new defense concept Russia founded an alternative security organization to NATO in Central Asia in 1997. Shanghai Security Organization member countries have clash of interest on their hegemonic power on rich energy resources in Central Asia (Özkan, 126). After the collapse of the Soviet Union, Russia and its orbit states economic, military and social relations have been changed with the orbit states political leaders (SDE, 124). Also Russia is not happy with US dominance in region. So in order to lessen US intervention they would prefer to have closer relations with Turkey which is heavily based on economic interest (SDE, 141). Turkey would enjoy the economic benefits of close relations with Russia and Muslim Turkish Republics even if with the expense of neglecting his western alliances such as EU and US (Ahmad, 264). So far it seems US lost against Russia but my expectation is it won't go long since after 2020 Russia has third disintegration process.

Our homeland Turkey in those times would reinforce its penetration and even move so far to Caucasus and Ukraine in order to create new crescent strategy around Russia. The ethno linguistic similarities and Ottoman Turkic past would also ease this policy. There is vast number of agencies and organizations playing an important role in development path of those countries. For example the success of cultural, economic and social projects of Turkish TIKA organization has positive impacts on Turkish presence after 1993 (Yesevi 262).

The spatial history in Central Asia has two main grounds in sociological claster analyses. The first one is religious identity which is dominated by Islam. The second one is ethnic identity which is dominated by Turkish ancestors. Those two elements in this region have living in daily social life and culture. Turkey would play important role in former USSR countries since they do share same religion (Fuller, 228). Those two sub identities had long live cultural heritage in Kazakhstan, Uzbekistan, Turkmenistan, Tataristan, Kirgizstan, Mongolia and Caucasus. Since first presence of different ethnic Turkish tribes nomad culture has grown in steppes and plains of Central Asia. Religious belief of those people was shamanism which is basically to adoration to naturel objects, mountains, sun and others. Shamanism is quite similar to old Roman pagan belief in a sense. From the very beginning till these days some daily habits and superstitious beliefs are very similar to old shamanic beliefs in Turkish culture such as water cult, nevroz and worship to sun and moon. There are also same daily routine in those geographic region, similar cousin, dressing and language. All these are embodied in the genetic code of cultural norms in all Turkish origin people. Following the islamisation of those tribes the second identity formation process began. The Sufi belief in this region reemerged and transmitted to western world by emigration of those tribes to Asia minor and Balkans in 11. Century. The colonization of Anatolia as old Roman country by those cultures created similar cultural origin from Central Asia.

The common spatial history and culture will build Turkish kalpahgh in Central Asia in 2030 and after. The Japan Turkish cooperation against Russia will also hamper Russian dominance on Turkic Republics (Passig, 223). Turkey will be new regional power between East and West with its considerable independent military and political power. The security of energy corridors in Hazar lake region will be the main priority of Turkish government. In order to maintain these aim military and other tools would be used in significant ways. This is the beginning of new big game (Özkan, 36). It is expected that competition among the USA.,EU, Turkey, Russia, China, Iran and other actors over the routes of oil and natural gas reserves of the region will be transported to the international markets will continue and Turkey will become one of the key countries of the east-west as well as 
the north-south energy corridor. As long as maintain sustainable economic growth and financial stability Turkey would also become energy market where almost $3 / 4$ of the entire world main energy supply in its neighbor countries. According to WEC estimations and some case studies this is one of the highest expectations in future (WEC, 59).

All these expectations are mainly based on strong performance of Turkish economy. It is the biggest economy among those countries and compared to neighbors it's the number one. There are some structural problems in Turkish economy such current account deficit and high unemployment rate. As long as solve cheap and sustainable energy supply and invest in competitive innovative new industries the possibility of successful economic model will be achieved in Turkey.

\section{Conclusion}

Spatial geoeconomic dimension one of the key elements in preserving common identity among Turkish speaking world. Most of jeoeconomic strategic theories put special emphasis on Turkic World in Central Asia. In this paper we briefly discussed Turkish presence in those Republics in historical context under the framework of cultural, spatial and economic dimensions. According to our expectations the new global players will be USA, Japan, Turkey and Poland. All these countries have common interest on Central Asia due to istrategic reasons. At the end of the paper we did some exploration for the future developments in Turkey regarding to those Republics in following decades. Turkish success for coming years in region is heavily depend upon its macroeconomic stability.

\section{References}

- Ahmet Yesevi Üniversitesi, Bağımsızlıklarının 20 Yılında Türki Cumhuriyetler, Uluslararası Sempozyumlar Dizisi Yayın No: 1 ISBN: 978-9944-237-13-0

- Ahmad Feroz, Modern Türkiye'nin Oluşumu, Kaynak yayınları, İstanbul,2009

- Aydın Mustafa, Üç Büyük Gücün Çatışma Alanı Kafkaslar, Gökkubbe yayınları, İstanbul, 2008

- Aydın Mustafa, Erhan Çağrı, Editörler, Beş Deniz Havzasında Türkiye, Siyasal Kitapevi, Ankara, 2006

- Dünya Enerji Konseyi Türkiye Milli Komitesi Enerji Senaryoları Çalışma Gurubu, Ankara,2007

- Ekrem Erkin, Çin'in Orta Asya Politikaları, Hoca Ahmet Yesevi Üniversitesi Araştırma Raporu, Ankara, 2011

- $\quad$ Findley Carter, Dünya Tarihinde Türkler, Kitap Yayıenevi, İstanbul,2006

- Friedman, Gelecek 100 Y11, Pegasus Yayınları, İstanbul 2011

- Fuller Graham, Lesser Ian, Balkanlardan Batı Çin’e Türkiyenin Yeni Jeopolitik Konumu, Alfa Yayınları, İstanbul,2000

- Özkan Gökhan, Türkiye'nin Orta Asya ve Kafkaslardaki Politikasında Enerji Güvenliği, Gazi Akademik Bakış, Cit 4 Sayı 7, Kış 2010

- Ö̈kan Gökhan, Soğuk Savaş Sonrasında Orta Asya ve Kafkasya Ekseninde Türkiye NATO Rusya İlişkileri ve Türk Dış Politikasına Yansımaları, Gazi Üniversitesi İktisadi ve İdari Bilimler Fakültesi Dergisi 12/1 (2010). 109-1322

- $\quad$ Passig David, 2050, Koton kitap, İstanbul,2011

- $\quad$ Stratejik Düşünce Enstitüsü, Rusya Raporu, Ankara,2010

- Strateji Yazıları, Milli Güvenlik Perspektifinden İç ve Dış Meseleler, ISBN: 978-975-19-6041-2, Milli Güvenlik Kurulu Genel Sekreterliği Yayınları, Ankara,2014

- Yılmaz, Sait, Güç ve Politika, Alfa Yayınları, İstanbul, 2008 